\title{
Surface change assessment of Co-Cr alloy subjected to immersion in denture cleansers
}

\author{
Pedro Carlos Cortiana Borsa', Mariana Marquezan², Liliana Gressler May ${ }^{3}$, Katia Olmedo Braun ${ }^{4}$ \\ ${ }^{1} \mathrm{MSc}$ in Prosthodontics, E-mail: pedroborsa@gmail.com Phone (55) 9938-5312, Private Practiner, Santa Maria, RS, Brazil \\ 2PhD in Orthodontics, E-mail: marianamarquezan@gmail.com Phone: (55) 9674-4678, Professor of the Department of Stomatology at Universidade \\ Federal de Santa Maria (UFSM), Santa Maria, RS, Brazil
}

${ }^{3} \mathrm{PhD}$ in Prosthodontics, E-mail: liligmay@gmail.com Phone: (55) 9141-8101, Professor of the Department of Restorative Dentistry at Universidade Federal

de Santa Maria (UFSM), Santa Maria, RS, Brazil

4PhD in Prosthodontics, E-mail: aitakbraun@gmail.com Phone: (55) 9971-3099, Professor of the Department of Restorative Dentistry at Universidade

Federal de Santa Maria (UFSM), Santa Maria, RS, Brazil

Received for publication: December 21, 2016 Accepted: May 27, 2017

\begin{abstract}
Choosing the right chemical cleanser for removable partial dentures is a challenge, because they present an acrylic and a metallic portion, which should be cleaned and not damaged. Aim: The aim of this study was to assess surface changes of cobalt chromium alloys immersed in different cleaners solutions: $0.05 \%$ sodium hypochlorite, $4.2 \%$ acetic acid, $0.05 \%$ sodium salicylate, sodium perborate (Corega Tabs $®$ ) and $0.2 \%$ peracetic acid. Material and Methods: One hundred and twenty circular specimens (10 mm in diameter) of two commercial available $\mathrm{Co}-\mathrm{Cr}$ alloys were tested: GM $800 \circledast$ (Dentaurum) and $\mathrm{Co}-\mathrm{Cr} \circledast$ (DeguDent). The samples were randomly divided into ten experimental groups $(n=10)$, according to the trend mark of alloy and cleaners solutions in which they were immersed, and two control groups, in which the samples of the two alloys were immersed in distilled water. Evaluations were performed through roughness measurement (rugosimeter Surftest 211, Mitutoyo), visual evaluation with stereomicroscope (Stereo Discovery 20, Carl Zeiss) and scanning electron microscope surface (JSM, 6360 SEM, JEOL), at experimental times T0 - before immersions, T1 - after one immersion, and T2 - after 90 immersions. Intergroup comparison for the effect of immersion in the different cleanser agents was evaluated through ANOVA/Tukey tests $(p \leq 0.05)$. The effect of the time in the immersion of each alloy was evaluated by $t$-pared test $(p \leq 0.05)$. The two alloys were compared using the t-Student test. Results: The analysis of roughness and microscopy showed that surface changes were significantly greater in groups submitted to $0.05 \%$ sodium hypochlorite after 90 immersions (T2). When comparing the two alloys, a similar behavior of roughness was observed for the cleaning agents. However, alloy GM $800 \circledR$ showed significant statistical difference for roughness variations in experimental times ( $\Delta 1$ and $\Delta 2$ ), when immersed in sodium $0.05 \%$ hypochlorite. The number of exposures of the alloys to the cleaning agents showed a negative influence when using sodium hypochlorite solution. Conclusions: It is possible to conclude that $0.05 \%$ sodium hypochlorite has caused the greatest apparent damage to alloy surface.
\end{abstract}

Keywords: Dental alloys, Chromium alloys; Denture Cleansers; Sodium Hypochlorite

\section{Introduction}

Despite advances in materials and techniques in dental rehabilitation, removable partial dentures (RPD) remain as an important tool for public health, because they are a less costly option ${ }^{1}$. Upon its installation in the oral cavity of patients, it is a dentist's 
duty to instruct them about hygiene ${ }^{2}$ to avoid the accumulation of biofilm, which is an etiological factor of oral diseases, such as caries and stomatitis. Patients can make use of mechanical and chemical cleaning methods. Their association has been reported in the literature as the best choice ${ }^{2-7}$, especially for special and geriatric patients, who find it difficult to properly brush their dentures ${ }^{1}$. Techniques and materials should be effective in cleaning, and should not affect the components of the prosthesis.

Of the chemical cleansers used for full dentures, sodium hypochlorite solutions deserve special attention, since they degrade mucin and allow for greater removal of bacterial biofilm in depth ${ }^{2,8}$. Solutions of sodium salicylate, sodium perborate, and acid peracetic are also used due to their antimicrobial potential ${ }^{8-10}$. A home-made option is vinegar (4.2\% acetic acid) capable of reducing the number of bacteria on the surface ${ }^{11}$.

Removable partial denture, however, present metallic components on their composition, normally cobalt chromium alloy $^{12}$. Choosing the right cleanser is a challenge, because solutions containing hypochlorites can cause some corrosion, staining, and even loss of physical properties ${ }^{13,14}$.

Thus, the aim of this study was to assess surface changes in cobalt chromium alloys subjected to immersion in different cleanser solutions: $0.05 \%$ sodium hypochlorite, $4.2 \%$ acetic acid, $0.05 \%$ sodium salicylate, sodium perborate (Corega Tabs $\left.{ }^{\circledR}\right)$ and $0.2 \%$ peracetic acid.

\section{Material and methods}

\subsection{Sample}

One hundred and twenty circular specimens $(10 \mathrm{~mm}$ in diameter) of two different alloys of Cr-Co - Remanium GM 800 (R) (Dentaurum, Pforzheim, Germany) and $\mathrm{Co}-\mathrm{Cr}{ }^{\circledR}$ Degudent (Dentsply Ind. and Co. Ltd, São Paulo, SP, Brazil) - were obtained through casting, polished with a sequence of wet sandpaper (600 to 2500) and diamond polishing paste with felt disk (Master Diamond Ferramentas, São Paulo, SP, Brazil) in polisher (Arotec APL-4, Arotec, Cotia, São Paulo, Brazil), numbered and randomly divided into 12 groups $(\mathrm{n}=10)$. Ten experimental groups were designed, according to cleanser solutions $-0.05 \%$ sodium hypochlorite, $4.2 \%$ acetic acid, $0.05 \%$ sodium salicylate, sodium perborate (Corega Tabs ${ }^{\circledR}$ ) and $0.2 \%$ peracetic acid; the type of alloy used (GM 800 (R) or $\mathrm{Co}-\mathrm{Cr}\left({ }^{\circledR}\right)$; and two control groups, where the bodies and specimens were immersed in distilled water (control).

The alloys used have more than $85 \%$ of chromium and cobalt in their compositions: GM $800 \circledR(63.3 \% \mathrm{Co} ; 30 \% \mathrm{Cr} ; 5 \% \mathrm{Mo} ; 1 \%$ $\mathrm{Si} ; 0.5 \% \mathrm{Mn} ; 0.4 \% \mathrm{C})$; $\mathrm{CoCr} \AA(64.8 \% \mathrm{Co} ; 28.5 \% \mathrm{Cr} ; 5.3 \% \mathrm{Mo}$; $0.5 \% \mathrm{Si} ;<1 \% \mathrm{Mn} ;<1 \% \mathrm{C} ;<1 \% \mathrm{~N})$. Sample size calculation was performed for mean difference of roughness and it was found that at least seven samples should be used to achieve $80 \%$ power. Thus, 8 specimens were used for roughness assessment, and 2 were intended for microscopic analysis.

\subsection{Immersion in cleansers}

The cleanser solutions were prepared and $15 \mathrm{ml}$ were poured into test tubes (Pyrex No. 9820, Corning Inc., USA), in which the specimens of each group were fully immersed.

For $0.05 \%$ sodium hypochlorite solution preparation, $5 \mathrm{ml}$ of $2.5 \%$ Sodium hypochlorite solution (Q-Boa ${ }^{\circledR}$, Anhembi S/A Osasco, São Paulo, Brazil) was diluted in $200 \mathrm{ml}$ of distilled water $^{6}$. Immersion time for this solution was 10 min per cycle ${ }^{15}$.

The $4.2 \%$ acetic acid solution consisted of pure white vinegar (WMS Supermercados do Brasil S/A, Porto Alegre, RS, Brazil). Immersion time for this solution was $10 \mathrm{~min}^{16}$.

The $0.05 \%$ sodium salicylate solution was prepared by diluting $1 / 4$ teaspoon $(0.25 \mathrm{~g})$ of sodium salicylate $\mathrm{PA}(\mathrm{C} 7 \mathrm{H} 5 \mathrm{NaO} 3)$ (Vetec Química Fina LTDA, Rio de Janeiro, RJ, Brazil) in 250 $\mathrm{ml}$ of distilled water. Immersion time for this solution was 15 minutes ${ }^{2}$.

Effervescent sodium perborate solution was prepared by diluting one tablet of Corega Tabs ${ }^{\circledR}$ (Stafford-Miller Ind., Rio de Janeiro, RJ, Brazil) in $150 \mathrm{ml}$ of water at $45^{\circ} \mathrm{C}$, as recommended by the manufacturer. Its immersion time was 15 minutes ${ }^{17}$.

The $0.2 \%$ peracetic acid solution was prepared by diluting $13.4 \mathrm{ml}$ of $15 \%$ peracetic acid (Sigmasul, Cachoeirinha, RS, Brazil) in one liter of distilled water. Immersion time for this solution was 15 minutes.

Surface assessments were held before immersions (T0), after one immersion (T1), and after 90 immersion cycles (T2), simulating the daily use of these solutions for three months. The samples were cleaned with spray of distilled water and dried on absorbent sheet, between each immersion, and the interval between consecutive immersions were merely the time necessary to wash and dry the specimens.

\subsection{Surface Roughness}

Surface roughness was measured using a rugosimeter (Surftest SJ 211, Mitutoyo Corp., Kanagawa, Japan), with 6 readings with cut-off of $0.25 \mathrm{~mm}$ in each specimen, 3 on the $\mathrm{x}$-axis ( $\mathrm{x}$ ) and 3 on the ordinate axis (y). The Ra parameter, which provides the means of peaks and valleys, was assessed in all experimental time intervals (T0, T1, and T2), using the center of the sample.

\subsection{Microscopic assessment}

Two microscopic analyses were performed. Initially, a stereomicroscope was used with magnification of $8.5 \mathrm{x}$ to assess samples in 3 experimental times. A damage index was created for the surface, where 0 indicates the absence of any signs of changes; 1 , the loss of brightness and light surface deposition; 2 , the occurrence of spots in more than two thirds of the surface of the specimens; and 3, the total darkening of the specimens. After that, Scanning Electron Microscopy (SEM) was performed with magnification of 500x, in order to view the topographic surface appearance of alloys. With the use of X-ray energy dispersive spectroscopy (EDS), it was possible to determine which chemical elements were present on the surface.

\subsection{Statistical analysis}

Data were tabulated and statistically analyzed using SPSS (Statistical Package for Social Sciences, version 13.0). Normality was verified by the Shapiro-Wilk test. Surface roughness after the application of cleaning protocols at times T1 and T2, as well as the difference found by subtracting roughness after immersion (in both 
times) by the initial roughness (baseline), were compared between different experimental groups by analysis of variance and multiple comparison Tukey test $(\mathrm{p} \leq 0.05)$. Roughness data after immersion in cleanser solutions were compared to initial (baseline) by paired $t$ test $(p \leq 0.05)$. The two alloys were compared with respect to roughness in the various protocols through t-Student test $(\mathrm{p} \leq 0.05)$.

The captured images of sample surface changes were visually assessed twice in an optical stereomicroscope by one observer, to yield a Kappa coefficient of 0.87 . The scores to visual changes underwent transformation "rank" to then be compared between the different experimental groups by analysis of variance and multiple comparison test of Tukey $(\mathrm{p} \leq 0.05)$. The two alloys were compared in scores of visual changes on different protocols by Mann-Whitney test $(\mathrm{p} \leq 0.05)$.

\section{Results}

\subsection{Surface Roughness}

Results showed no statistically significant difference between the methods of cleaning after the first immersion as to roughness (T1). After 90 immersions (T2), the means of $\mathrm{Ra}(\mu \mathrm{m})$ in the groups submitted to $0.05 \%$ sodium hypochlorite were significantly higher (Table 1). Other cleansers did not cause surface roughness changes in the alloy over time (Table 1). When comparing the two alloys, we have found similar behavior in roughness for cleansers. However, alloy GM $800 \AA$ showed significant statistical difference between $\Delta 1$ and $\Delta 2$ when immersed in $0.05 \%$ sodium hypochlorite (Table 2).

Table 1 - Mean and standard deviation (SD) of surface roughness Ra $(\mu \mathrm{m})$ of alloys immersed in various cleansers in experimental times.

\begin{tabular}{|c|c|c|c|c|}
\hline Alloy & Solution & $\operatorname{Ra}(\mu \mathrm{m})-\mathrm{TO}$ & $\operatorname{Ra}(\mu \mathrm{m})-\mathrm{T1}$ & $\operatorname{Ra}(\mu \mathrm{m})-\mathrm{T} 2$ \\
\hline \multirow{6}{*}{$\mathrm{Co}-\mathrm{Cr} \circledast$} & $0.05 \%$ sodium hypochlorite & $0.050(0.009)^{\mathrm{aA}}$ & $0.063(0.011)^{\mathrm{aB}}$ & $0.494(0.083)^{\mathrm{bC}}$ \\
\hline & $4.2 \%$ acetic acid & $0.061(0.017)^{\mathrm{aA}}$ & $0.070(0.027)^{\mathrm{aA}}$ & $0.059(0.021)^{\mathrm{aA}}$ \\
\hline & $0.05 \%$ sodium salicylate & $0.061(0.016)^{\mathrm{aA}}$ & $0.068(0.035)^{\mathrm{aA}}$ & $0.083(0.037)^{\mathrm{aA}}$ \\
\hline & Sodium perborate (Corega Tabs $₫$ ) & $0.047(0.006)^{\mathrm{aA}}$ & $0.060(0.019)^{\mathrm{aB}}$ & $0.067(0.010)^{a \mathrm{~B}}$ \\
\hline & $0.2 \%$ peracetic acid & $0.052(0.013)^{\mathrm{aA}}$ & $0.067(0.029)^{\text {аАВ }}$ & $0.080(0.032)^{\mathrm{aB}}$ \\
\hline & Distilled water - control & $0.062(0.021)^{\mathrm{aA}}$ & $0.069(0.018)^{\mathrm{aA}}$ & $0.060(0.011)^{\mathrm{aA}}$ \\
\hline \multirow{6}{*}{ GM $800 \circledast$} & $0.05 \%$ sodium hypochlorite & $0.053(0.015)^{\mathrm{aA}}$ & $0.077(0.021)^{\mathrm{aB}}$ & $1.254(0.191)^{\mathrm{bC}}$ \\
\hline & $4.2 \%$ acetic acid & $0.073(0.019)^{\mathrm{aA}}$ & $0.088(0.023)^{\mathrm{aA}}$ & $0.103(0.048)^{\mathrm{aA}}$ \\
\hline & $0.05 \%$ sodium salicylate & $0.062(0.026)^{\mathrm{aA}}$ & $0.068(0.026)^{\mathrm{aA}}$ & $0.072(0.027)^{\mathrm{aA}}$ \\
\hline & Sodium perborate (Corega Tabs $®$ ) & $0.062(0.017)^{\mathrm{aA}}$ & $0.074(0.021)^{\mathrm{aB}}$ & $0.074(0.018)^{\mathrm{aAB}}$ \\
\hline & $0.2 \%$ peracetic acid & $0.085(0.034)^{\mathrm{aA}}$ & $0.099(0.042)^{\mathrm{aA}}$ & $0.084(0.032)^{\mathrm{aA}}$ \\
\hline & Distilled water - control & $0.072(0.023)^{\mathrm{aA}}$ & $0.087(0.038)^{\mathrm{aA}}$ & $0.075(0.033)^{\mathrm{aA}}$ \\
\hline
\end{tabular}

Different lowercase letters indicate statistically significant difference between the immersion solutions, with the same alloy and time (ANOVA/Tukey, $\mathrm{p} \leq 0.05)$.

Different capital letters indicate statistically significant difference among immersion times (t-pared test, $\mathrm{p} \leq 0.05)$.

Table 2 - Mean and standard deviation (SD) of the variation of roughness after $1(\Delta 1)$ and 90 immersions $(\Delta 2)$.

\begin{tabular}{llll}
\hline Solutions & & Co-Cr® & GM 800® \\
\hline \multirow{2}{*}{$0.05 \%$ sodium hypochlorite } & $\Delta 1$ & $0.013(0.012)^{\mathrm{a}}$ & $0.024(0.017)^{\mathrm{a}}$ \\
& $\Delta 2$ & $0.446(0.085)^{\mathrm{a}}$ & $1.202(0.194)^{\mathrm{b}}$ \\
$4.2 \%$ acetic acid & $\Delta 1$ & $0.008(0.030)^{\mathrm{a}}$ & $0.014(0.024)^{\mathrm{a}}$ \\
& $\Delta 2$ & $0.000(0.028)^{\mathrm{a}}$ & $0.030(0.042)^{\mathrm{a}}$ \\
$0.05 \%$ sodium salicylate & $\Delta 1$ & $0.007(0.041)^{\mathrm{a}}$ & $0.007(0.034)^{\mathrm{a}}$ \\
& $\Delta 2$ & $0.021(0.037)^{\mathrm{a}}$ & $0.010(0.021)^{\mathrm{a}}$ \\
sodium perborate (Corega Tabs $囚)$ & $\Delta 1$ & $0.014(0.017)^{\mathrm{a}}$ & $0.010(0.013)^{\mathrm{a}}$ \\
& $\Delta 2$ & $0.022(0.014)^{\mathrm{a}}$ & $0.010(0.029)^{\mathrm{a}}$ \\
0.2\% peracetic acid & $\Delta 1$ & $0.013(0.025)^{\mathrm{a}}$ & $0.015(0.045)^{\mathrm{a}}$ \\
& $\Delta 2$ & $0.028(0.034)^{\mathrm{a}}$ & $0.000(0.037)^{\mathrm{a}}$ \\
distilled water - control & $\Delta 1$ & $0.002(0.021)^{\mathrm{a}}$ & $0.003(0.020)^{\mathrm{a}}$ \\
& $\Delta 2$ & $0.071(0.030)^{\mathrm{a}}$ & $0.083(0.036)^{\mathrm{a}}$ \\
\hline
\end{tabular}

Different letters indicate statistically significant differences among alloys for roughness variation $\Delta 1$ and $\Delta 2$ with the same cleansers $(\mathrm{p} \leq 0.05)$.

\subsection{Microscopic Assessment}

After one immersion (T1) no clear visual change was noted on the surface of any of the groups. However, after 90 immersions (T2), the two alloys submitted to $0.05 \%$ sodium hypochlorite presented the highest scores, pointing to the major changes (Table 3).

Table 3 - Mode of visual scores after 90 immersions (T2).

\begin{tabular}{lll}
\hline Solutions & Co-Cr® & GM $800 \AA$ \\
\hline $0.05 \%$ sodium hypochlorite & $2^{\mathrm{aA}}$ & $3^{\mathrm{aB}}$ \\
$4.2 \%$ acetic acid & $0^{\mathrm{bB}}$ & $0^{\mathrm{cB}}$ \\
$0.05 \%$ sodium salicylate & $1^{\mathrm{bB}}$ & $1^{\mathrm{bB}}$ \\
Sodium perborate (Corega Tabs 8$)$ & $0^{\mathrm{bB}}$ & $0^{\mathrm{cB}}$ \\
$0.2 \%$ peracetic acid & $0^{\mathrm{bB}}$ & $1^{\mathrm{bC}}$ \\
Distilled water - control & $1^{\mathrm{bB}}$ & $0^{\mathrm{cB}}$ \\
\hline
\end{tabular}

Different lowercase letters indicate statistically significant difference between the columns (difference between the alloys - Mann-Whitney test, $\alpha=0.05$ ). Different capital letters indicate statistically significant difference between the lines (difference between immersion solution - ANOVA/Tukey, $\alpha=0.05$ ). 
In further analysis by SEM, it was possible to observe sharpening occurrence, suggesting a slight texturing of the surface of the $\mathrm{Co}-\mathrm{Cr}{ }^{\circledR}$ alloy after the first immersion. However, after the ninetieth immersion, widespread surface change was noticed, with the presence of protruding clusters and occasional depressions (Figure 1). For the GM $800 \AA$ alloy, after the first immersion, minimal superficial change was noticed. However, after the ninetieth immersion, the image shows more abrupt changes in the structure of the sample (Figure 2). EDS surface analysis of both alloys, when immersed in $0.05 \%$ sodium hypochlorite, showed the presence of oxygen and chlorine, which indicates corrosion. Iron and tungsten were also found in the composition of alloy GM $800 \AA$, not reported by the manufacturer.

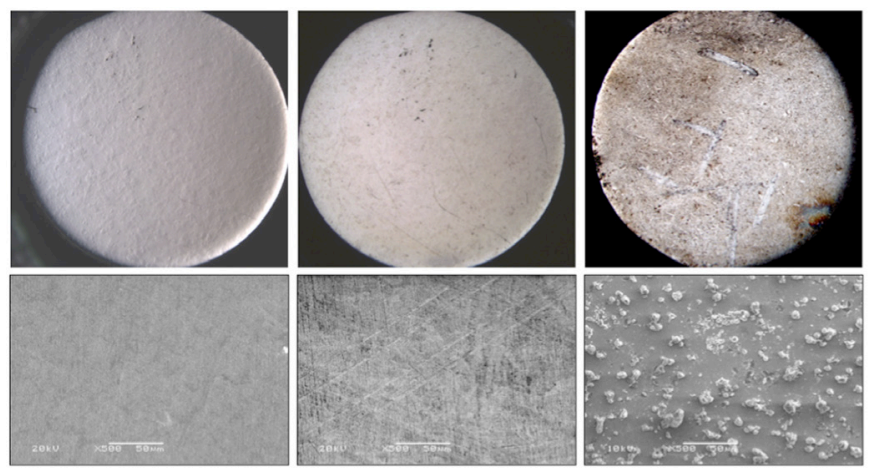

Fig. 1 - Co-Cr® alloy specimen immersed in $0.05 \%$ sodium hypochlorite solution in the three experimental times (a: T0; b: T1; c: T2). Above there is the stereomicroscope image (Magnification of 8.5x). Below, SEM images (magnification of 500x). T1 shows little change in surface brightness (score 1 ), while T2 shows a widespread staining on the surface (score 2).

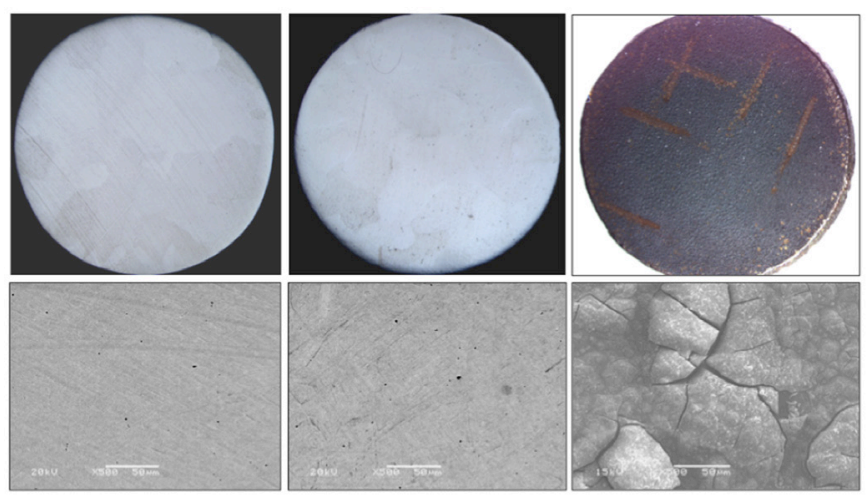

Fig. 2 - GM $800 ®$ alloy specimen immersed in $0.05 \%$ sodium hypochlorite solution in all three experimental days (a: T0; b: T1; c: T2). Above there is the stereomicroscope image (magnification 8.5x). Below, SEM images (magnification 500x). T1 shows little change in the surface brightness (score 1), while T2 is observed to such darkening the surface and abrupt changes in relief.

\section{Discussion}

When choosing a metal for facing different challenges in hostile environments, its corrosion behavior its corrosion behavior is the most important factor to be considered ${ }^{18}$. Thus, this work has compared the $\mathrm{Co}-\mathrm{Cr} \AA$ e GM $800 \AA$ metal cobalt chromium alloys, after being immersed in 5 cleaners.
Regarding cleanser comparison, $0.05 \%$ sodium hypochlorite solution caused more obvious changes to alloy, generating higher roughness values and higher scores on the analysis with stereomicroscope. Analysis of roughness after immersion of the alloy in $4.2 \%$ acetic acid solution, $0.05 \%$ sodium salicylate, sodium perborate (Corega Tabs ${ }^{\circledR}$ ) and $0.2 \%$ peracetic acid, showed no statistically significant difference between experimental periods with no increased roughness over time. It was also observed that water-immersed alloys (control) had scores of 0 and 1 , with slight loss of brightness (score 1) only seen with a microscope and not to the naked eye. Therefore, we decided to consider these two as having no damage. Thus, $4.2 \%$ acetic acid solution, $0.05 \%$ sodium salicylate, sodium perborate (Corega Tabs ${ }^{\circledR}$ ), and $0.2 \%$ peracetic acid did not cause visible damage to alloys at different experimental times.

When the alloys were compared, it was observed that, with regard to roughness, the nominal values of $\mathrm{Ra}(\mu \mathrm{m})$ were higher for GM $800 \AA$, but with no statistically significant difference. However, statistically significant difference has been found for $\Delta 1$ and $\Delta 2$ for this alloy. With the stereomicroscope, clearer changes were observed for alloy GM 800® after 90 immersions (T2). The evaluation by SEM confirmed most surface changes for this alloy at $\mathrm{T} 2$. As for the $\mathrm{CoCr} \AA$ alloy, it showed superficial changes similar to those that occur when superficial electrochemical attack is conducted with acid solution to metallographic analysis ${ }^{19}$, with the view of protruding beads on the surface of the alloy. GM 800® alloy showed greater degree of change with suggestive image of detachment of surface oxidation plates. It is believed that the observed difference for the two alloys at T2 may be related to the fact that GM $800 \AA$ has shown iron and tungsten in its composition, which was identified by EDS, since the presence of other metals in the alloy can modify its corrosion resistance and increase the speed of etching ${ }^{20}$.

It is believed that surface roughness of the alloy reaches clinical significance when reaching $0.2 \mu \mathrm{m}$, which favors the adhesion of biofilm. Thus, values higher than this cannot be clinically accepted ${ }^{21}$. In this study, the two alloys exceeded this cut-off point after 90 immersion in $0.05 \%$ sodium hypochlorite $(\mathrm{Co}-\mathrm{Cr} \AA=0.446 \mu \mathrm{m} ; \mathrm{GM} 800 \AA=1.202 \mu \mathrm{m})$, which suggests that $0.05 \%$ sodium hypochlorite may cause damage the Co-Cr alloys used in RPD, which agrees with the literature ${ }^{2,13,14,22}$. Although sodium hypochlorite has fungicidal ${ }^{8,16,23}$ and bactericide effect, and is able to penetrate up to $3 \mathrm{~mm}$ in the resin, not only eliminating the surface bacteria, but also those in depth, if allowed to act for ten minutes, at a concentration of $0.525 \%{ }^{15}$, its use in RPD should be cautious due to the deleterious effects on metal infrastructure. Recent studies have demonstrated the damaging effect of sodium hypochlorite on the alloy Co-Cr by weight and ion $\operatorname{loss}^{22}$, and by reducing the modulus of elasticity and ultimate strength. In the latter study, however, the property of bending was found satisfactory according to ADA specification No.1424.

With respect to the quantity of infused over time, only groups exposed to sodium hypochlorite $0.05 \%$ showed obvious changes after the first immersion. Comparing evaluations in SEM's first exposure to hypochlorite (T1) with the evaluation after 90 exposures (T2), it is clear that there was a real deterioration of the surface of the two alloys, which is higher in the alloy (GM 
800 ( )). The visual scores evaluation showed scores 2 and 3 after dipping 90 cycles, while after the first immersion the score was 0 , agreeing with results of previous studies ${ }^{25,26}$.

With the exception of the groups submitted to $0.05 \%$ sodium hypochlorite solution, there was no occurrence of surface damage to the alloy. Therefore, it is possible to perform removable partial denture cleaning with most solutions used in the study. However, further studies are needed for evaluating the mechanical properties of alloys, as well as evaluate more immersions.

\section{Conclusion}

The solution of $0.05 \%$ sodium hypochlorite showed significant surface changes, suggestive corrosion, while other solutions did not present such deleterious effects. Both alloys showed similar surface changes after 90 immersion cycles for different cleansers. Increased contact with cleansers caused greater surface changes on the alloy only when $0.05 \%$ sodium hypochlorite solution was used.

\section{References}

1. Sesma N, Takada KS, Laganá DC, Jaeger RG, Azambuja Jr N. Eficiência de métodos caseiros de higienização e limpeza de próteses parciais removíveis. Rev Assoc Paul Cir Dent. 1999;53:463-68.

2. Budtz-Jorgensen E. Materials and methods for cleaning dentures. $J$ Prosthet Dent. 1979 Dec;42(6):619-23.

3. Dills SS, Olshan AM, Goldner S, Brogdon C. Comparison of the antimicrobial capability of an abrasive paste and chemical-soak denture cleaners. J Prosthet Dent. 1988 Oct;60(4):467-70.

4. Kulak Y, Arikan A, Albak S, Okar I, Kazazoglu E. Scanning electron microscopic examination of different cleaners: surface contaminant removal from dentures. J Oral Rehabil. 1997 Mar;24(3):209-15.

5. Nikawa H, Jin C, Makihira S, Egusa H, Hamada T, Kumagai H. Biofilm formation of Candida albicans on the surfaces of deteriorated soft denture lining materials caused by denture cleansers in vitro. J Oral Rehabil. 2003 Mar;30(3):243-50.

6. Barnabe W, de Mendonca Neto T, Pimenta FC, Pegoraro LF, Scolaro JM. Efficacy of sodium hypochlorite and coconut soap used as disinfecting agents in the reduction of denture stomatitis, Streptococcus mutans and Candida albicans. J Oral Rehabil. 2004 May;31(5):453-9.

7. Paranhos HF, Silva-Lovato CH, Souza RF, Cruz PC, Freitas KM, Peracini A. Effects of mechanical and chemical methods on denture biofilm accumulation. J Oral Rehabil. 2007 Aug;34(8):606-12.

8. de Freitas Fernandes FS, Pereira-Cenci T, da Silva WJ, Filho AP, Straioto FG, Del Bel Cury AA. Efficacy of denture cleansers on Candida spp. biofilm formed on polyamide and polymethyl methacrylate resins. J Prosthet Dent. 2011 Jan;105(1):51-8. doi: 10.1016/S00223913(10)60192-8.

9. Chassot AL, Poisl MI, Samuel SM. In vivo and in vitro evaluation of the efficacy of a peracetic acid-based disinfectant for decontamination of acrylic resins. Braz Dent J. 2006;17(2):117-21.

10. Svidzinski AE, I. P, Pádua RAF, Tavares TR, Svidzinski TIE. Eficiência do ácido peracético no controle de Staphylococcus aureus meticilina resistente. Cienc Cuidado Saude. 2007;6:312-8.

11. Shay K. Denture hygiene: a review and update. J Contemp Dent Pract. 2000 Feb 15;1(2):28-41.

12. Geurtsen W. Biocompatibility of dental casting alloys. Crit Rev Oral Biol Med. 2002;13(1):71-84.

13. Kastner C, Svare CW, Scandrett FR, Kerber PE, Taylor TD, Semler HE. Effects of chemical denture cleaners on the flexibility of cast clasps. J Prosthet Dent. 1983 Oct;50(4):473-9.

14. Keyf F, Gungor T. Comparison of effects of bleach and cleansing tablet on reflectance and surface changes of a dental alloy used for removable partial dentures. J Biomater Appl. 2003 Jul;18(1):5-14.

15. Chau VB, Saunders TR, Pimsler M, Elfring DR. In-depth disinfection of acrylic resins. J Prosthet Dent. 1995 Sep;74(3):309-13.

16. da Silva FC, Kimpara ET, Mancini MN, Balducci I, Jorge AO, Koga-Ito $\mathrm{CY}$. Effectiveness of six different disinfectants on removing five microbial species and effects on the topographic characteristics of acrylic resin. J Prosthodont. 2008 Dec;17(8):627-33. doi: 10.1111/j.1532849X.2008.00358.x.

17. Guidelines for infection control in the dental office and the commercial dental laboratory. Council on Dental Therapeutics. Council on Prosthetic Services and Dental Laboratory Relations. J Am Dent Assoc. 1985 Jun;110(6):969-72.

18. Upadhyaya D, Panchal MA, R.S. D, Srivastava VK. Corrosion of alloys used in dentistry: a review. Mater Sci Engin. 2006;432(1-2):1-11.

19. de Sousa LL, de Felipe Hd, Codaro EN, Nakazato RZ. Electrochemical and microstructural study of Ni-Cr-Mo alloys used in dental prosthesis after different remelting processes. Corros Proteccao Mater. 2010;29(2):42-8.

20. Rincic N, Baucic I, Miko S, Papic M, Prohic E. Corrosion behaviour of the Co-Cr-Mo dental alloy in solutions of different composition and different pH values. Coll Antropol. 2003;27 Suppl 2:99-106.

21. Bollen CM, Lambrechts $P$, Quirynen M. Comparison of surface roughness of oral hard materials to the threshold surface roughness for bacterial plaque retention: a review of the literature. Dent Mater. 1997 Jul;13(4):258-69.

22. Felipucci DN, Davi LR, Paranhos HF, Bezzon OL, Silva RF, Barbosa Junior $F$, et al. Effect of different cleansers on the weight and ion release of removable partial denture: an in vitro study. J Appl Oral Sci. 2011 Oct;19(5):483-7.

23. de Sousa Porta SR, de Lucena-Ferreira SC, da Silva WJ, Del Bel Cury AA. Evaluation of sodium hypochlorite as a denture cleanser: a clinical study. Gerodontology. 2015 Dec;32(4):260-6. doi: 10.1111/ger.12104.

24. Papadopoulos T, Polyzois G, Tapanli A, Frangou M. The effect of disinfecting solutions on bending properties and weight changes of $\mathrm{Co}-\mathrm{Cr}$ and Ti-6Al-7Nb alloys for dentures. Odontology. 2011 Jan;99(1):77-82. doi: 10.1007/s10266-010-0135-2.

25. McGowan MJ, Shimoda LM, Woolsey GD. Effects of sodium hypochlorite on denture base metals during immersion for short-term sterilization. J Prosthet Dent. 1988 Aug;60(2):212-8.

26. Schalch MV, Adabo GL, Souza RF, Fonseca RG, Cruz CAS. Corrosion resistance of dental alloys submitted to disinfection. Rev Odontol UNESP. 2004;33(3):143-8. 